\title{
Characteristics Planning Strategies of Southern Shaanxi Towns Based on Ecological and Humanistic Ideas
}

\author{
Dingqing ZHANG \\ Department of Architecture \\ Xi'an Jiaotong University \\ Xi'an, China \\ e-mail: zhangdq@xjtu.edu.cn \\ Yaping SUN \\ Department of Architecture \\ Xi'an Jiaotong University \\ Xi'an, China \\ e-mail: sundan0109@foxmail.com
}

\author{
Lin YANG \\ Department of Architecture \\ Xi'an Jiaotong University \\ Xi'an, China \\ e-mail: ylpolyu921008@163.com
}

\author{
Wei GUO \\ Department of Architecture \\ Xi'an Jiaotong University \\ Xi'an, China \\ e-mail: williamguo@xjtu.edu.cn
}

\begin{abstract}
Southern Shaanxi region has abundant featured resources. However, due to lack of guidance of characteristics planning theories and methods, small towns gradually lost their own characteristics in the rapid development. Based on the interpretation of the concept and constitution of town's characteristics, featured resources and current problems in Southern Shaanxi towns are analyzed, and then the planning and design concepts that could highlight the ecological and cultural characteristics of the region are proposed. Combined with case study, characteristic status of town is determined and specific characteristics planning strategies are put forward from the macro, meso and micro levels.
\end{abstract}

Keywords-small towns; ecology and humanity concepts; characteristics planning

\section{INTRODUCTION}

Characteristic is something's style and form significantly different from other things, and it is determined by specific environmental factors that things developed upon. Small town's characteristics are comprehensive reflection of its physical form and social and cultural features [1], usually with unique forms of expression, to reflect the town's personality.

In the process of town's rapid development, due to the lack of guidance of characteristics planning theories and methods that leads to the destruction of natural and cultural characters, crisis of characteristic has become a problem that could not be ignored in town planning. Under the consideration of natural and cultural background of Southern Shaanxi region, small town's characteristics planning strategies are discussed in hopes of providing references to current urbanization practice.

\section{CONCEPTION AND CONSTITUTION OF TOWN'S CHARACTERISTICS}

Small town's characteristics are essential attributes of factors that constitute the town and are systems consisted of natural environment features, social and economic features and regional culture features. The reflection of these characteristics first come from environmental factors and featured resources upon which the town formed and developed. Town's featured resources are natural resources, human resources and artificial environment resources that, to some extent, could create towns' characteristics (refer with: Table I ). Small town's characteristics can be recognized based on the essential attributes and unique personalities demonstrated by its featured resources.

\section{CHARACTERISTICS ANALYSIS AND CURRENT PROBLEMS OF TOWNS IN SOUTHERN SHAANXI}

\section{A. Abundant Featured Resources of Towns}

Southern Shaanxi is located between the Qinling and Tapa Mountains where river systems are rich and terrains are undulate. The geomorphology types are Qinling Mountains, Ta-pa Mountains and hills and river basins around Han River which results in the geomorphology of "river basin between mountains" (refer with: Fig.1).

There is favorable climate, abundant flora and fauna. Excellent geographical location and natural environment gives Southern Shaanxi towns unique characteristics in the ecological environment and natural landscape.

Furthermore, Southern Shaanxi region has a long history. Its geographical location east to Central Plains and south to Bachu area makes it the integration of the Ba-Shu culture, Jing-Chu culture and Central Plains culture [2]. Under the influence of multicultural background, this region has rich cultural heritage and historical sites, and gives small towns unique charm in lifestyle, customs and traditional architectural style. 


\section{B. Traditional Towns with Distinctive Features}

TABLE I. CONSTITUTION OF TOWN's FEATURED RESOURCES

\begin{tabular}{|c|c|c|}
\hline Featured Resources & Meaning & Constitution \\
\hline Natural resources & $\begin{array}{l}\text { characteristic environmental factors, the physical } \\
\text { basis and ecological security of town's construction } \\
\text { and development }\end{array}$ & $\begin{array}{l}\text { topography, river systems, climate, forests, } \\
\text { biological, mineral and other natural elements }\end{array}$ \\
\hline Human resources & $\begin{array}{l}\text { historical and cultural resources, irreplaceable } \\
\text { elements of town's characteristics }\end{array}$ & $\begin{array}{l}\text { cultural ideas, historical allusions, historical sites, } \\
\text { customs, religious beliefs and crafts, traditional } \\
\text { industries and other human factors }\end{array}$ \\
\hline $\begin{array}{l}\text { Artificial environment } \\
\text { resources }\end{array}$ & $\begin{array}{l}\text { consists of built environment space resources and } \\
\text { landscape resources, important expression of } \\
\text { town's image }\end{array}$ & $\begin{array}{l}\text { spatial structure and fabrics, buildings, } \\
\text { environmental facilities, parks, green spaces, } \\
\text { squares and other elements of the built environment }\end{array}$ \\
\hline
\end{tabular}

Relying on the rich natural resources and human resources, traditional small towns in Southern Shaanxi exhibit a variety of characteristics in layout, space, traditional culture and other aspects.

Most of the small towns are hillside and waterfront. There are three types of geographic patterns which are basin plains, hilly area and mountain area, where the towns show different space characteristics such as slug concentration, zonal distribution and free dispersion (refer with: Table II, Fig. 2). Development of small towns adapts to the regional environment and reflects humanistic philosophy and simple ecological ideas in traditional residence construction, including respect to nature, site selection and integration of human and nature.

Southern Shaanxi region has rich cultural heritage and is influenced by different cultural origins, mainly merchants culture, collecting and fishing culture, farming culture which directly influence the industrial activities and public life, and reflect the different cultural characteristics (refer with: Table III).

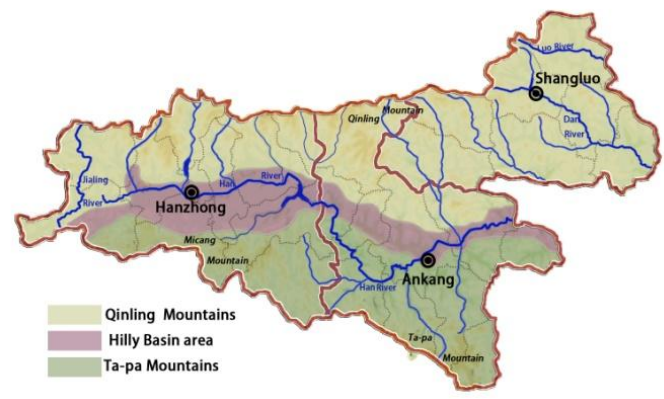

Figure 1. Geomorphology of southern Shaanxi

Thus, the formation and development of traditional small towns in Southern Shaanxi takes advantages of mountains and rivers and other natural resources, reflecting ecological thinking and construction concepts of the harmony with nature and local conditions, thus gives birth to a unique regional culture, as well as living environment with ecological and cultural characteristics.

\section{Current Problems of Town's Characteristics}

In rapid urbanization process, due to poor protection and utilization of featured resources, the problem of lack of town's characteristics becomes more prominent in Southern Shaanxi. On the one hand, the characteristics of the natural environment in built areas become weaker caused by overexploitation of resources in the town expansion process, ecological destruction, inconsistence of townscape and natural environment. On the other hand, historical and cultural features of towns are in recession: the destruction of historical and cultural heritage, imitation to the big cities with square and tall buildings or archaizing with blindness, not only lack of innovation, but also damage to the original style.

\section{IV.CHARACTERISTICS PLANNING STRATEGIES OF SOUTHERN SHAANXI TOWNS - A CASE STUDY OF QINGMUCHUAN}

\section{A. Town's Characteristics Planning Concepts Based on Ecology And Humanity Ideas}

With the guidance of ecological concept, effective protection and rational utilization of local natural environment should be carried out in town construction that is conductive to the formation of town's unique landscape qualities and enhances its recognition.

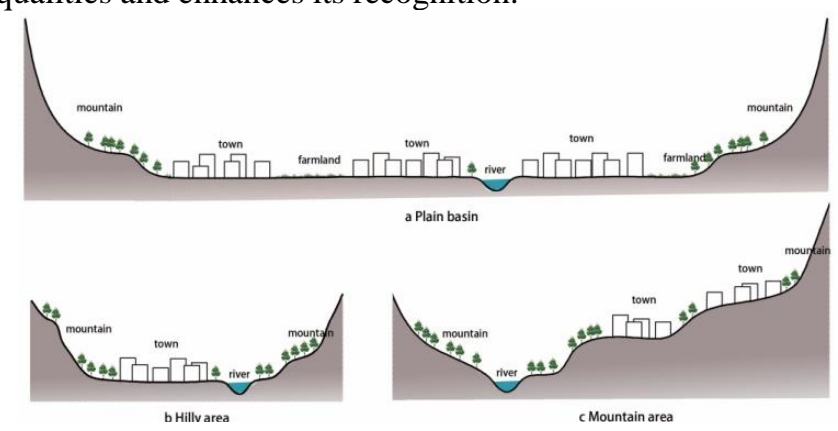

Figure 2. Sketch map of townscape pattern

Therefore, based on adequate research in present situation and features of the natural environment and historical and cultural resources of small towns, featured resources should be analyzed, and planning concepts of ecology and humanities should be used. The planning and design strategies and methods that could highlight the ecological and cultural characteristics of region could be practiced from master plan - urban design - architectural design levels. 
TABLE II. LANDSCAPE PATTERn AND SPATIAL FEATURES OF TOWN UNDER ENVIRONMENTAL IMPACT

\begin{tabular}{|c|c|l|c|}
\hline $\begin{array}{c}\text { Geomorpholog } \\
\text { y }\end{array}$ & $\begin{array}{c}\text { Space Form of } \\
\text { Towns }\end{array}$ & \multicolumn{1}{|c|}{ Layout and Space Features } & Examples \\
\hline Plain basin & Slug concentration & $\begin{array}{l}\text { Towns stand on plain basin that has flat terrain and } \\
\text { undulating ground. They are usually near river for } \\
\text { convenient farming. Space of towns is slug gathering and } \\
\text { more structured. They have compact layout and grid-based } \\
\text { roads. }\end{array}$ & $\begin{array}{c}\text { Shangyuanguan Town } \\
\text { Xiecun Town }\end{array}$ \\
\hline Hilly area & Zonal distribution & $\begin{array}{l}\text { Towns are located in valley of hilly areas and relatively } \\
\text { gentle hillside areas. Because of the terrain, most of towns } \\
\text { develop along sides of the river and become zonal areas, } \\
\text { and the land is narrower. }\end{array}$ & $\begin{array}{c}\text { Qingmuchuan Town } \\
\text { Dihua Town }\end{array}$ \\
\hline Mountain area & Free dispersion & $\begin{array}{l}\text { Towns are built in mountain land with steep slope. They } \\
\text { are located in hillside or valley, the small clumps along } \\
\text { different elevation. Influenced and restricted by terrain, the } \\
\text { building groups are free dispersion. }\end{array}$ & $\begin{array}{c}\text { Manchuanguan Town } \\
\text { FenghuangTown } \\
\text { Huayang Town }\end{array}$ \\
\hline
\end{tabular}

TABLE III.

TOWN's CHARACTERISTICS UNDER DIFFERENT CULTURAL ORIGINS INFLUENCE

\begin{tabular}{|c|l|c|}
\hline Cultural Origins & \multicolumn{1}{|c|}{ Industry and Life Characteristics } & Examples \\
\hline Merchants culture & $\begin{array}{l}\text { Convenient transportation, goods distribution center, frequent activities of } \\
\text { modern Merchants Chamber, prosperous commercial trade, distribution of } \\
\text { guildhall and traditional commercial street }\end{array}$ & $\begin{array}{c}\text { Shuhe Town } \\
\text { Qingmuchuan Town } \\
\text { Longjuzhai Town } \\
\text { Huayang Town }\end{array}$ \\
\hline $\begin{array}{c}\text { Collecting and fishing } \\
\text { culture }\end{array}$ & $\begin{array}{l}\text { High mountains and dense forests, abundant water resources and forest } \\
\text { products, ideas of reliance on nature, more Taoist architectural monuments }\end{array}$ & $\begin{array}{c}\text { Chang'an Town } \\
\text { Pingliang Town } \\
\text { Yankou Town } \\
\text { Huangu Town }\end{array}$ \\
\hline Farming culture & $\begin{array}{l}\text { Flat land and easy irrigation, abundant rice and other crops, Confucius } \\
\text { culture as the ideological basis, relatively rich ethical color }\end{array}$ & $\begin{array}{c}\text { Yangchun Town } \\
\text { Luohe Town } \\
\text { Dagui Town }\end{array}$ \\
\hline
\end{tabular}

\section{B. Investigation and Evaluation of Featured Resources}

Town's featured resources survey is the basis of characteristics planning, and resources evaluation is a prerequisite for the protection and innovation of town's characteristics. Based on evaluation of town's featured resources, types of town's characteristics and their connotation would be clear and characteristics shaping priorities would be determined.

Taking Qingmuchuan Town of Ningqiang County in Hanzhong as an example, its featured resources of qualitative analysis are showed as follows (refer with: Table IV, Fig. 3). Qingmuchuan is at the junction of Shaanxi, Gansu and Sichuan provinces and was an important commercial town in history. It is rich in natural and human resources with zonal shape in valley and could be determined as a cultural experience and natural sightseeing tourist town. Shaping of town's characteristics concentrates on eco-construction, and the focus should be the cultural experience from traditional town.

\section{Town's Characteristics Planning and Design Strategies}

\section{1)Construction of townscape layout at macro level:}

The characteristics planning at the macro-level is controlled in town master planning. Based on town's characteristics position, featured resources and ecological environment should be protected and utilized through planning structure, town layout, road system, functional organization and special industries planning, and then the construction of townscape layout would be in harmony with nature.

Qingmuchuan Town is located in Jinxi riverside between the Phoenix Mountain and Longchi Mountain, facing rivers and behind mountains, and its space form is a curved strip along the river. However, the completion of the new street makes the whole town space appear breaking point, without close connection between the old and new districts [3]. At the macro planning level, the whole town space should be the continuation of "a river between two mountains" landscape pattern and layout, and the new planning should conform to the trend of mountains and rivers to organize road network and continue old street texture in order to form harmonious space.

Taking into account the connection of views of both sides of the mountain, both old and new district sight permeability and functional contact would be realized in form of streets, open space or green land (refer with: Fig. 4). In the industry planning, the town can rely on a strong cultural atmosphere and rich cultural resources to form "sightseeing participation - experience" cultural tourism service chain and create a series of tourism products. 
TABLE IV.

FEATURED RESOURCES IN QINGMUCHUAN TOWN

\begin{tabular}{|c|l|}
\hline \multicolumn{1}{|c|}{ Resources } & \multicolumn{1}{c|}{ Characteristics } \\
\hline Natural resources & $\begin{array}{l}\text { Valley, hilly landscape, rich landscape resources, a national nature reserve, rare wild plant } \\
\text { and animal species }\end{array}$ \\
\hline Human resources & $\begin{array}{l}\text { Merchant Culture, Wei Futang, Qingmu tree and other legends and folk tales, Wei's Mansion, } \\
\text { Hongshengchang Store, Furen School and other historic buildings }\end{array}$ \\
\hline Artificial environment resources & $\begin{array}{l}\text { Ribbon spatial form, Huilong Street and traditional houses, riverside boardwalk, the new } \\
\text { town street }\end{array}$ \\
\hline
\end{tabular}

\section{2) Shapingtownscape at meso-level:}

Most part of characteristics planning at meso-level is the shaping of townscape at urban design level, which should concentrate on combination of local folk traditions and history and culture. It may be introduced into the "urban characteristics planning" concept and conduct townscape system planning that converges to macro-level with elements of "landscape core", "landscape axis" and "landscape nodes" [4].

The landscape core is usually historic district or representative landscape area including important cultural and historical landscape in town and natural landscape; landscape axis is linear landscape element like historic street or riverfront shoreline; landscape nodes are landscape centers in axis or sub-regions. Based on the natural geographical environment and historical and cultural environment, landscape units of point, line and surface pattern combine with each other to form landscape system and strengthen local landscape with a strong cultural atmosphere.

Landscape design in Qingmuchuan could use Jinxi River as a major natural landscape axis, form landscape core near Feifeng Bridge to connect the new and old district, and use historical buildings like Furen School, Wei's Mansion as landscape nodes. Those nodes connect with natural landscape axis through cultural landscape axis. Meanwhile, the design focuses on the protection of Jinxi River in order to build ecological corridor and realize the reflection of natural environment and human environment.

The old and new streets should have coordination of certain style and function, and the architectural style, scale, color of new street should be controlled as a whole. The old

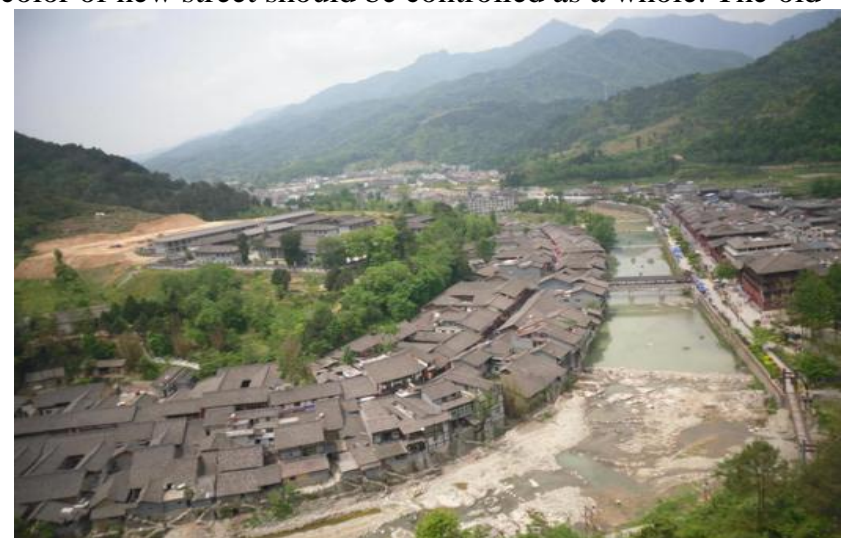

Figure 3. Aerial view of Qingmuchuan town street provides guidance to the style of new street and the new provides supplementary function to the old.

3)Reflecting characteristics of the built environment at micro level:

At the micro level, shaping of town's characteristics is mainly reflected in the architectural and environmental design. Architecture style should be integrated with the local culture and should extract special symbols, spatial connotation of traditional architectural styles like roof form, ratio, color, material and space scales, etc. Modern design techniques could help achieve coordination and harmonization in the layout and facade color, etc. Environment facilities should be designed to integrate into the local cultural meaning and help shape characteristics of town.

Existing buildings in old Street of Qingmuchuan are mainly buildings from Ming and Qing Dynasties, and residential buildings are mostly soil-wood structures with courtyard. Gray tile roofs and whitewashed walls merge with natural environment of mountains and rivers. In the process of building protection and renewal, typical architectural features in streets should be extracted, such as using patio courtyard layout and scattered arrangement along the terrain and continuation of street texture. Selection of facade materials should take into consideration the mix use of wood, brick, stone to emphasize local architectural features. Environmental facilities should match the architecture in color, material and appearance and integrate with the local landscape.

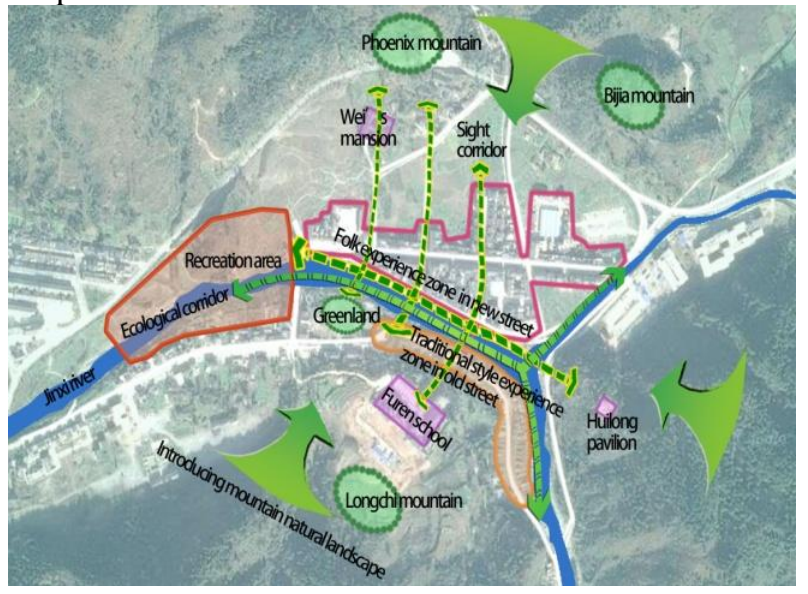

Figure 4. Analysis diagram of Qingmuchuan spatial structure 


\section{CONCLUSION}

Based on analysis of current situation and featured resources survey and evaluation, small town's characteristics planning should determine characteristic development direction and integrate with ecology and humanity ideas. The specific planning and design strategies and methods are presented from the macro, meso and micro levels, to construct townscape layout, shape townscape and reflect the characteristics of the built environment. The natural and cultural characteristics of small towns should be highlighted by means of planning and design to construct town's living environment with ecological harmony and rich culture.

\section{ACKNOWLEDGMENT}

This work was financially supported by the Fundamental Research Funds for the Central Universities (xjj2015129).

\section{REFERENCES}

[1] Yaping Huang, Jin Wang, "Discussion on the shaping of the small town's features," Urban Problems, pp. 6-9, March 2006.

[2] Yan Zhang, "Research of methods to building town image of small towns with features in Southern Shaanxi," Xi'an: Chang'an University, 2010.

[3] Jing Zhang, "Qingmuchuan Town spatial characteristics and protection strategy," Xi'an: Chang'an University, 2015.

[4] Chong Chen, "Urban planning method study of the best livable small town," Nanjing: Southeast University, 2004. 